\title{
Pengaruh Market Value Added Terhadap Harga Saham Pada Perusahaan Manufaktur
}

Dimas Julistyo

Universitas Sumatera Utara, Indonesia

Corresponding Author: juicydee54@gmail.com

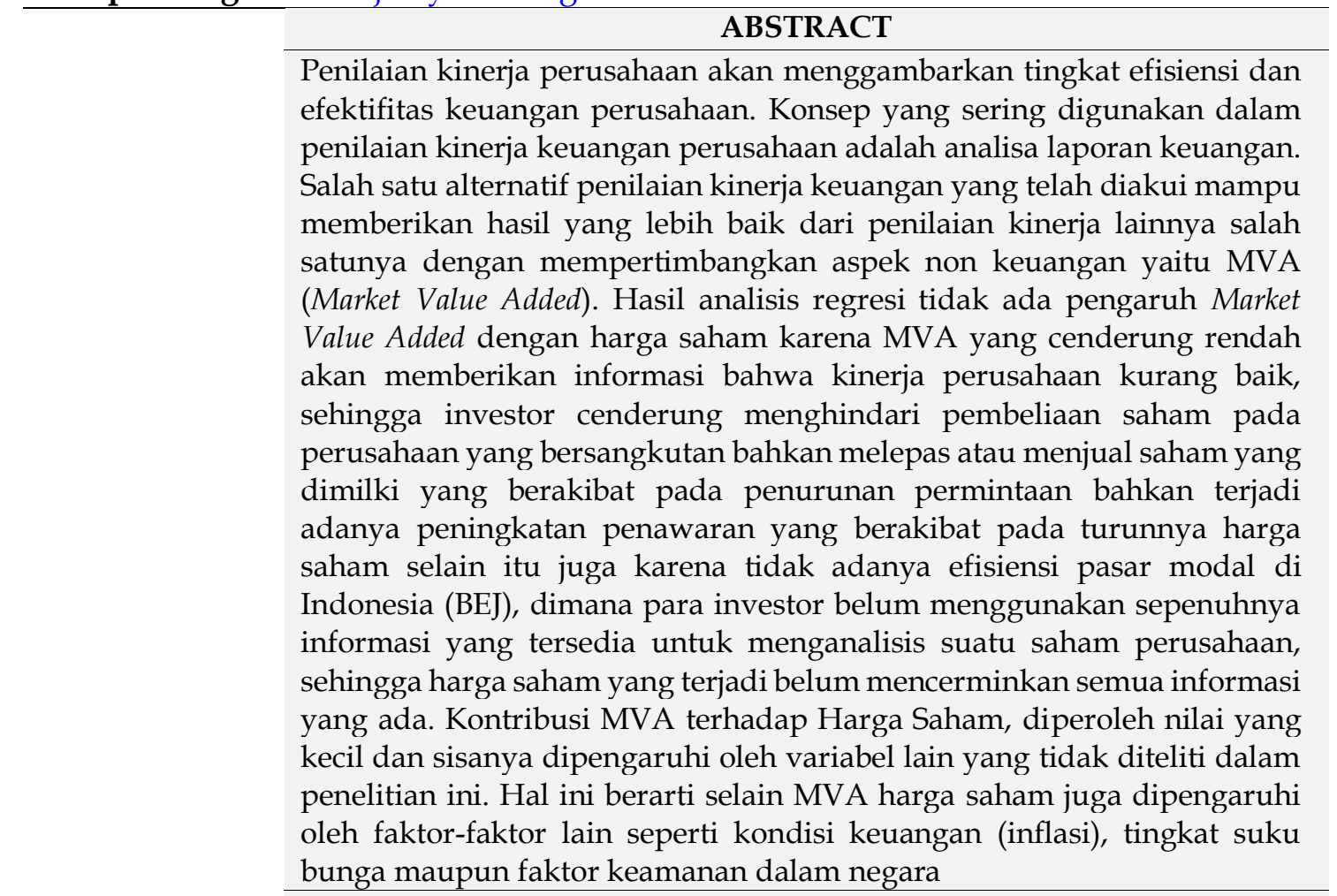

Keywords

MVA, Harga Saham, Manufaktur

\section{PENDAHULUAN}

Kehadiran pasar modal di Indonesia ditandai dengan banyaknya investor yang mulai menanamkan sahamnya dalam industri konstruksi. Bisnis manufaktur baik residensial maupun komersial menunjukkan perkembangan yang cukup pesat di Indonesia, terbukti dengan semakin maraknya pusat bisnis dan supermall dalam tahun-tahun terakhir. Selain itu ditunjukkan dengan semakin tingginya pertumbuhan kinerja sektor manufaktur dalam dua tahun terakhir dibanding dengan sektor-sektor ekonomi lainnya yaitu sebesar 10,32\% untuk tahun 2019 dan 10,75\% untuk tahun 2020 (Jawa Pos, 18 Januari 2021).

Laporan keuangan digunakan perusahaan sebagai salah satu alat mengukur kinerja perusahaannya. Selain itu, laporan keuangan dapat digunakan untuk mengetahui perubahan dari tahun ke tahun, serta dapat 
digunakan juga untuk mengetahui perkembangan perusahaan. Laporan keuangan bertujuan untuk menyediakan informasi yang menyangkut posisi keuangan, kinerja, serta perubahan posisi keuangan yang bermanfaat bagi sebagian besar pemakai dalam pengambilan keputusan ekonomi.

Salah satu alternatif penilaian kinerja keuangan yang telah diakui mampu memberikan hasil yang lebih baik dari penilaian kinerja lainnya salah satunya dengan mempertimbangkan aspek non keuangan yaitu MVA (Market Value Added). MVA merupakan metode yang mengukur seberapa besar nilai tambah yang berhasil diberikan perusahaan kepada para penyandang dana. Berkaitan dengan kata "market", maka konsep ini tidak terlepas atau perlu adanya penilaian pasar, sehingga menurut Sterwart (1996) dalam Baridwan (2002) bahwa MVA hanya dapat dihitung atau diaplikasikan pada perusahaan publik atau yang listed di pasar modal. Konsep ini juga menuntut diterapkan pasar modal yang efisien yang harga sahamnya mencerminkan seluruh informasi yang tersedia (Mirza, 1997) dalam Baridwan (2002). Dalam kaitannya dengan investasi saham, investor memilih saham perusahaan yang layak untuk dipilih berdasarkan kriteria tertentu. Menurut Purnomo (2001), kriteria yang umum digunakan adalah yang aktif diperdagangkan dan fundamentalnya bagus.

Investor yang rasional akan mempertimbangkan dua hal yaitu pendapatan yang diharapkan (expected return) dan risiko (risk) yang terkandung dalam alternatif investasi yang dilakukan. Harga pasar saham adalah market clearing prices yang ditentukan berdasarkan kekuatan permintaan dan penawaran (Purnomo, 2001). Jadi harga saham adalah nilai suatu saham yang mencerminkan kekayaan perusahaan yang mengeluarkan saham tersebut, dimana perubahan atau fluktuasinya sangat ditentukan oleh kekuatan penawaran dan permintaan yang terjadi di bursa (pasar sekunder). Semakin banyak investor yang ingin membeli atau menyimpan suatu saham, harganya semakin naik, sebaliknya semakin banyak investor yang ingin menjual atau melepaskan suatu saham, harganya semakin bergerak turun. Dengan menggunakan konsep MVA diharapkan perusahaan dapat mengukur tingkat kemakmuran atau maksimisasi nilai perusahaan. Kinerja perusahaan akan menentukan tinggi rendahnya harga saham di pasar modal. MVA yang positif diharapkan berdampak pada kenaikan harga saham perusahaan.

\section{METODE PENELITIAN}

Review tentang pengaruh Market Value Added terhadap harga saham pada perusahaan manufaktur menggunakan metode kualitatif dengan teknik pendektan survei literatur akademik melalui daring. Metode kualitatif dipilih karena penelitian yang bersifat deskriptif dan cenderung menggunakan analisis. Proses dan makna (perspektif subjek) lebih ditonjolkan dalam penelitian kualitatif. Landasan teori dimanfaatkan sebagai pemandu agar fokus penelitian sesuai dengan fakta di lapangan. Teknik analisis dokumen yaitu pencarian data dengan menggunakan sumber tertulis yang mencerminkan pemakaian bahasa 
sinkronis (Edi Subroto, 2010). Dimana peneliti mengakses google scholar, lembaga kajian, jurnal dan media masa terkait hasil kajian, informasi, hasil penelitian, dokumen kementerian, dokumen lembaga internasional, analis kebijakan pengelolaan keuangan negara yang terdampak pandemi.

\section{HASIL DAN PEMBAHASAN}

Keseluruhan dari hasil analisis data berikut temuan penelitian terdahulu secara ringkas dapat dikemukakan sebagai bahan untuk membahas hasil-hasil penelitian ini. Berdasarkan hasil analisis deskripsi pengaruh MVA terhadap harga saham, dari perhitungan secara keseluruhan untuk semua perusahaan dari tahun 2019 - 2020, perusahaan menghasilkan nilai MVA positif maupun MVA negatif. MVA yang positif menandakan bahwa nilai pasar perusahaan lebih tinggi daripada nilai buku perusahaan sehingga investor tertarik untuk menanamkan modalnya pada perusahaan tersebut. Sebaliknya, jika MVA perusahaan negatif menandakan nilai pasar perusahaan tersebut lebih rendah daripda nilai buku perusahaan sehingga, investor tidak tertarik untuk menanamkan modalnya pada perusahaan tersebut. Market Value Added (MVA) merupakan pengukuran kinerja yang menunjukkan besarnya kekayaan yang diciptakan oleh perusahaan bagi kepentingan investor atau perbedaan antara yang diperoleh investor (total market value) dengan jumlah yang dikeluarkan oleh investor (invested capital). Market Value Added (MVA) dihitung dari hasil pengurangan nilai pasar dengan nilai nominal per lembar saham, kemudian dikalikan dengan jumlah saham. Nilai pasar menggambarkan keberhasilan manajer dalam menginvestasikan modal dari para investor. Kekayaan atau kesejahteraan pemilik perusahaan (pemegang saham) akan bertambah bila Market Value Added (MVA) bertambah.

MVA yang rendah akan memberikan informasi bahwa kinerja perusahaan kurang baik, sehingga investor cenderung menghindari pembeliaan saham pada perusahaan yang bersangkutanbahkan melepas atau menjual saham yang dimilki yang berakibat pada penurunan permintaan bahkan terjadi adanya peningkatan penawaran yang berakibat pada turunnya harga saham. Hal ini disebabkan karena tidak adanya efisiensi pasar modal di Indonesia (BEJ), dimana para investor belum menggunakan sepenuhnya informasi yang tersedia untuk menganalisis suatu saham perusahaan, sehingga harga saham yang terjadi belum mencerminkan semua informasi yang ada. Kontribusi MVA terhadap Harga Saham, diperoleh dipengaruhi oleh variabel lain yang tidak diteliti dalam penelitian ini. Hal ini berarti selain MVA harga saham juga dipengaruhi oleh faktor-faktor lain seperti kondisi keuangan (inflasi), tingkat suku bunga maupun faktor keamanan dalam negara. Inflasi membuat adanya penurunan mata uang rupiahterhadap mata uang asing sehingga bila terjadi inflasi investor lebih suka investasi dalam bentuk mata uang asing dan enggan membeli saham dan akibatnya volume permintaan turun. Suku bunga yang tinggi membuat investor lebih suka investasi dalam bentuk depositon dan obligasi sehingga permintaan saham turun dan harga juga merosot. Pada faktor keamanan suatu negara bila 
dinilai tidak aman akan membuat investor lebih suka untuk melakukan investasi ke luar negeri sehingga volume.

\section{KESIMPULAN}

Penelitian ini menguji pengaruh Market Value Added (MVA) terhadap harga saham pada perusahaan manufaktur yang terdaftar di bursa efek. Analisis data yang digunakan adalah analisis deskriptif dan analisis regresi. Hasil analisis deskriptif ditemukan pengaruh MVA terhadap harga saham, dari perhitungan secara keseluruhan untuk semua perusahaan dari tahun 2019 - 2020, perusahaan menghasilkan nilai MVA positif maupun MVA negatif. Trend rata - rata MVA tahun 2019 dan tahun 2020 menunjukkan arah menurun. Hasil analisis regresi tidak ada pengaruh Market Value Added dengan harga saham karena MVA yang cenderung rendah akan memberikan informasi bahwa kinerja perusahaan kurang baik, sehingga investor cenderung menghindari pembeliaan saham pada perusahaan yang bersangkutanbahkan melepas atau menjual saham yang dimilki yang berakibat pada penurunan permintaan bahkan terjadi adanya peningkatan penawaran yang berakibat pada turunnya harga saham selain itu juga karena tidak adanya efisiensi pasar modal di Indonesia (BEI), dimana para investor belum menggunakan sepenuhnya informasi yang tersedia untuk menganalisis suatu saham perusahaan, sehingga harga saham yang terjadi belum mencerminkan semua informasi yang ada. Kontribusi MVA terhadap Harga Saham, diperoleh nilai yang kecil dan sisanya dipengaruhi oleh variabel lain yang tidak diteliti dalam penelitian ini. Hal ini berarti selain MVA harga saham juga dipengaruhi oleh faktor-faktor lain seperti kondisi keuangan (inflasi), tingkat suku bunga maupun faktor keamanan dalam Negara.

\section{PENGAKUAN/ PENGHARGAAN}

Penulis ucapkan terima kasih kepada Universitas Sumatera Utara khususnya Fakultas Ekonomi dan Bisnis, serta kepada Dosen Perkuliahan Manajemen Keuangan Lanjutan Ibu Prof. Dr. Isfenti Sadalia, S.E, M.E atas segala ilmu-ilmu yang telah diberikan selama perkuliahan.

\section{REFERENCES}

Dewi Sri Harjanti, “Analisis Manfaat EVA dalam Pengukuran Nilai perusahaan dan Kesejahteraan Pemegang Saham Pada Perusahaan Publik di BEJ", Kajian Bisnis dan Manajemen, Vol 4, No 2, 2002.

Ikatan Akuntan Indonesia (IAI), "Standar Akuntansi Keuangan”, Salemba Empat, Jakarta, 2004. Indonesian Capital Market Directory. 2005, Bursa Efek Jakarta, Jakarta. Jogiyanto. 2000. Teori Portofolio dan Analisis Investasi. Edisi II. Yogyakarta: BPFE UGM.

Kanti Atria R, “Analisis Hubungan EVA dan MVA Pada Perusahaan Yang Terdaftar di BEJ", Skripsi S-1 Fakultas Ekonomi Universitas Islam Indonesia, 2004. 
Lisa Linawati Utomo, “EVA Sebagai Ukuran Keberhasilan Kinerja Manajeman”, Jurnal Akuntansi dan Keuangan, Vol 1, No 1, Mei, 1999.

O'Byrne, F. Stephen dan S. David Young. 2001. Economic Value Added dan Manajemen Berdasarkan Nilai Panduan Praktis untuk Implementasi. Jakarta: Salemba Empat.

Pradhono \& Yulius Jogi Cristiawan, "Pengaruh EVA, Residual Income, Earnings dan Arus Kas Operasi Terhadap Return Yang Diterima Oleh Pemegang Saham", Jurnal Akuntansi dan Keuangan, Vol 6, No 2, November, 2008.

Rokhayati Eliyah, "Perbandingan Kinerja Keuangan Pada Perusahaan Makanan dan Minuman Yang Go Publik di BEJ dengan Metode EVA dan ROA", Skripsi S-1, Fakultas Ekonomi Universitas Islam Indonesia, 2003.

Robert N. Anthony \& Vijay Govindarajan, penerjemah F.X. Kurniawan Tjakrawala, M.Si.Ak, "Sistem Pengendalian Manajemen", Edisi Pertama, Salemba Empat, Jakarta, 2002. Shidarta Utama, "EVA: Pengukuran dan Penciptaan Nilai Peusahaan", April, 1997.

Majalah:

Majalah Swasembada, No 20-23, 2011. 